\title{
AN AMERICAN WOMAN THROUGH THE PRISM OF THE EPITHET: SEMASIOLOGICAL ASPECT IN CREATING IMAGES
}

\author{
Halyna Stashko
}

Stashko, H. (2017). An American woman through the prism of the epithet: semasiological aspect in creating images. In Lege artis. Language yesterday, today, tomorrow. The journal of University of SS Cyril and Methodius in Trnava. Warsaw: De Gruyter Open, 2017, vol. II (2), December 2017, p. 356391. DOI: 10.1515/lart-2017-0012 ISSN 2453-8035

\begin{abstract}
The paper describes the use of epithets in creating female images in American folk songs. The results of the stylistic analysis show how different types of epithets intensify female images and testify to the connection between semantics and culture. Multifunctionality of the epithet tends to be of paramount importance in creating and interpreting images and backgrounds to them in folk song texts. This synergy provides valuable and handy clues, which help understand the evolution of a woman in America.
\end{abstract}

Key words: epithet, classification of epithets, epithet structure, female images, American song folklore.

\section{"... Epithets, like pepper, \\ Give zest to what you write; And if you strew them sparely, \\ They whet the appetite: But if you lay them on too thick, You spoil the matter quite! ..." Lewis Carroll}

\section{Introduction}

There is truth in folklore, which enables us to use it as a source of social experience that needs no proof. Moreover, folklore in America is now at its peak of revival both in music sphere and in science (Panasenko 2013, 2014), which again proves its ageless conservative style and accuracy in identity and mentality matters. Thus, one argument in support of this statement is that American folklore has been researched by a number of linguists (Bauman \& Abrahams 1981; Brunvand 1978; Hymes 1981; Levitsky 2016; 
Panasenko 2013, 2014; Volkova 2016). As America has been undeniably democratic and freedom-oriented, its folklore provides case studies of establishment of women throughout ages in terms of their background, family, and social status.

When researching the issue of sound symbolism (Stashko 2016, 2016a, 2017) in creating female images in American song folklore, I came across a peculiar feature in man-and-woman relations, namely that "men mostly tend to hide their hard-hitting personal feelings due to hypothetic public disapproval and find it apposite to focus on natural phenomena while addressing women" (Stashko 2017).

It is generally believed that women are more emotional than men, at least they show their emotions publicly. Therefore, the first thing, which can be fact-checked, is the assumption that in songs women use more epithets when presenting their part. On the contrary, men are presumably less wordy and flamboyant in terms of expressing their feelings towards women. At least, it is possible to observe this course of things, presented in books on psychology and in general fiction. Though taking into consideration that individuals are different and cultures that shaped them are different as well, we may witness an algorithm typical of a nation and maintained by generations if folklore shows repeated signs of particular customs or traditions.

Thus, in connection to stereotypes, it can be assumed that traditional folk songs will have quite an amount of trite epithets as they represent views that are more conservative whereas authors usually tend to be rich in expressing their emotions in their art. Bearing in mind all the above-stated points, it may seem that popular folk songs that have authors will show more expressive means and stylistic devices with the epithet included, as poets are considered more professional in poetic styles.

Assuming these, the aim of the research is to trace the link between gender and means of expressing emotions and feelings to further identify the role of the epithet in 
perception and creation of female images and clarify whether the research results on sound symbolism (Stashko 2016; 2017) prove to be corroborated.

\section{Materials and methods}

As far as the epithet is concerned, the focus was on the selected American folk songs, which contain epithets. In this work, 100 folk songs in question have been analyzed with the help of qualitative and quantitative content analyses and 50 of them have been researched comprehensively. In total, five collections of American folk songs (Appleby 1991; Kingman 1990; Malkoç 1994; Raph 1986; Sandburg 1936) have been used. What is more, the first thing that needs to be said is that the indicated sources feature both folk and author songs, which are also considered 'folk' in America. Moreover, author songs are generally accepted as 'popular' and those whose author is unknown are termed 'traditional' (Panasenko 2014; Sandburg 1936).

Another relevant point to be indicated is the time frames of the selected folk song corpus. As America is a comparatively young country, its folklore is rich in accurate dates. In the recent paper, the historical period of 1800-1955 has been embraced to illustrate the diversity of culture, traditions, origins, and identities.

Regarding the matter of the author's personal subjectivity in descriptions, respective blurred considerations are therefore possible. However, linguistics has favoured individual perceptions of certain issues so far.

\section{The epithet in studies}

\subsection{Definition and functions of the epithet}

To start with, it is crucial to provide several relevant definitions and terms linked to the issue. The word 'epithet' originates from the $16^{\text {th }}$ century either from French épithète, or via Latin from Greek epitheton, neuter of epithetos 'attributed', from epitithenai 'add', from epi 'upon' + tithenai 'to place' (EOLD, s.a.). 
The epithet is a characterizing word or phrase accompanying or occurring in place of the name of a person or thing (MWOD, s.a.), e.g., white wine. Some dictionaries specify that a characterizing word or phrase is an adjective expressing a quality or attribute regarded as characteristic of the person or thing mentioned (CED, s.a.; EOLD, s.a.), e.g., sweet eyes. Halliday \& Matthiessen (2004) support this viewpoint in functional grammar stating that the epithet is typically filled by adjectives or participles; as it shows quality of the noun it is combined with either describing the object itself or subjectively indicates the speaker's attitude to the very object. Banfield (1982) specified that the noun phrase with the structure ' $\mathrm{X}$ of $\mathrm{Y}^{\prime}$ is also considered the epithet when involves evaluative nouns, e.g., that idiot of a doctor.

However, one should not forget that the epithet differs from the descriptive attribute, which shows the inherent property of a thing, thus being objective and non-evaluating.

In contemporary use, most dictionaries speak of the epithet as of a stylistic device, which is used as a way of praising or criticizing someone (CED, s.a.), often as an insult (CFEDT, s.a.), e.g., clumsy idiot. In ordinary use the epithet may become a nickname (CED, s.a.; Wales, 2001: 141), e.g., America the Beautiful, Philip the Fair.

In poetry the epithet traditionally serves as 'an ornament' and is presented by adjectives (golden heart), nouns (eyes of ecstasy), participles (fallen idol), and sometimes numerals (seventh sense). It functions to make a reader or a listener feel and evaluate situations exactly the way an author wants to.

As we can see, epithets fulfill different stylistic functions, such as descriptive (to portray characters, views, situations, objects, and feelings); expressive (to make texts more emotional), evaluative (to show the described characters' features and feelings), and individualizing (to define individual characteristics of people and objects).

Galperin gives the most comprehensive and accurate explanation of the epithet (1981: 157): 
The epithet is a stylistic device based on the interplay of emotive and logical meaning in an attributive word, phrase or even syntactically used to characterize an object and pointing out to the reader, and frequently imposing on him, some of the properties or features of the object with the aim of giving an individual perception and evaluation of these features or properties. $<\ldots>$ It is markedly subjective and evaluative, $<\ldots>$ subtle and delicate in character.

Therefore, the epithet is considered an important tool, which is primarily essential in folk songs that are concise in storytelling and therefore need devices to illustrate as many details as possible.

Moreover, epithets are important to convey an author's psychological and emotional state. They depict minor details in constructing and decoding emotions, feelings, atmosphere, background, and generally all issues, which are mostly intangible. Besides, they help a listener feel a real participant in described situations.

\subsection{Classification of epithets}

Before turning to the research results discussion, it is worth considering the matter of classifications of epithets. Previous studies indicate that there exist several of them. Galperin (1981), for example, based his classification on three principles:

1) the semantic principle;

2) the principle of the relationship between the epithet and the word it relates to;

3) the structural principle.

Semantically (1) epithets are divided into two groups:

1) associated with the noun following it; they point to the most essential features of an object in focus (dark sea);

2) unassociated with the noun following it; they characterize an object adding to it the similarity that may be inherent to it only under conditions depicted in the text (careless winds). This similarity may seem strange, unusual or even unexpected.

According to the principle of relationships (2), there are language (aka traditional / conventional / fixed / trite / standing) epithets (true love), which function as stable 
word-combinations that are distinguished by simplicity, high predictability, and insignificant stylistic effect, and speech (aka original) epithets (sleepless bay), created by authors or ordinary speakers to solve certain stylistic problems that do not have a clear interpretation and are primarily expressive. The first are characteristic of folklore and lexical groups close to folklore.

From the point of view of their compositional structure (3) we distinguish the following structural models of epithets:

a) simple epithets, expressed by simple adjectives, nouns, participles (loud street);

b) compound epithets, expressed by compound adjectives (cherry-eyed boy);

c) phrase epithets (do-it-yourself attitude);

d) sentence epithets, expressed by integrated sentences ( $a$ 'well-that's-the-story-whatare-we-going-to-do-about-it' air);

e) reversed epithets, where the core is an adjunct ( $a$ hell of a pretty girl). They are composed of two nouns linked by an 'of phrase'.

With regard to epithets and female images, this classification corpus is of paramount importance, in as much as it will serve the basis for the brand new division tailored for the research. In order to link it to the research results, the very data will be suggested in the paragraph below.

\section{Discussion}

To optimally present the research results the information will be provided gradually, starting with general observations on the matter to specific points linked to the core of the study.

\subsection{Figures and general observations}

Let us start by considering the figures. Roughly speaking, half of the analysed folk songs have no epithets at all. This tide traces no obvious connection to imagery. There are folk songs both with female and male images that feature epithets. For example, 
"Annie Lisle" numbers three epithets to describe the dead girl (sweet Annie Lisle, happy smile, angel music), "Lily of the West" contains two epithets that illustrate Flora's beauty (rosy cheeks, ruby lips) and "I'll take you home again, Kathleen" shows the best features of Kathleen with the help of four epithets (loving eyes, loving heart, bonnie bride, true heart). Those with male images are "Cowboy Jack" with two relevant epithets in the cowboy's description field (brave heart, true heart) and "The strawberry Roan", which depicts a bad man using four epithets (pigeon toes, pig eyes, pin ears, old belly). The findings suggest that the use of epithets is a "key" that is well-known to the general public and describes the image concisely.

However, epithets are not represented in quite a number of folk songs with female ("Ida red", "Good night, Irene") and male images ("Billy boy", "Cumberland gap"). This fact does not prove the paucity of imagery descriptions of the given songs though. Moreover, there is no evident dependence between images and epithets, as there often are other relevant stylistic devices to depict images. To the author's supposition, simplicity of folk songs may be the reason for the limited number of stylistic devices. The absence of epithets does not diminish vivid descriptions of characters, as this function is often transferred to other stylistic devices and music.

To illustrate the zero influence of stylistic simplicity on images let us refer to the traditional folk song of unknown origin "Ida red". In my opinion, this feature does not "simplify" the female image, but rather strengthens its certain features and thus attracts most attention to them.

\section{Ida Red, Ida Blue, \\ I got stuck on Ida too.}

Refrain:

Down the road and across the creek,

Can't get a letter but once a week. 


\section{Ida Red, Ida Green,}

Prettiest girl you've ever seen.

Refrain

\section{Ida Red, Ida Gold,}

She is somethin' to behold.

Refrain

\section{Ida Red, Ida Red,}

That girl's sweeter than gingerbread.

The first aspect that needs to be mentioned is the image of a pretty girl, which is depicted with the help of hyperbole (prettiest girl you've ever seen) and simile (that girl's sweeter than gingerbread). Hyperbole, which is a deliberate, often extravagant exaggeration of the qualities of an object or a phenomenon (MWOD, s.a.), directly appeals to the imagination of the recipient and is a direct, not veiled display of emotions. In the respective folk song hyperbole increases expressiveness and feelings to the girl, adds up to the empathetic character of the song.

Furthermore, the comparison of Ida to gingerbread is also indicative of her immense beauty. In the United States, especially among Catholics, gingerbread has long been a symbol of Christmas and holiday. Fragrant and beautiful gingerbread has been considered a wonderful gift, because in ancient times ginger root was a sign of luxury and its price was inferior (Ginger, s.a.; Sandburg 1936). Thus, for Americans, the comparison of a girl with gingerbread has a special significance. She is valued and respected in the society like a real treasure.

It should not be forgotten though that a song also has melodic component (Panasenko 2013, 2014). Melody often conveys more imagery and "covers" lexically unsaturated or completely neutral poetic texts, which may even seem senseless. From the very beginning, a text without a melody offers simple and slightly strange female images and creates the impression of rhythmic chaos, which, in its turn, emphasizes stability 
of the inherent features. Melodic component is linked with syntactic expressive means, represented by anaphora and ordinary repetition (Ida Red, Ida Blue), which contribute to rhythm and balance.

\subsection{The epithet VS other semasiological devices}

Further study of the issue would be of interest too. The overall quantitative results referring to the usage of stylistic devices in American folk songs are summarized in Figure 1, where it can be seen that the epithet is the most recurrent device (see Stashko 2016a for comparison).

Other means do not dominate quantitatively; however, this fact does not diminish their role in the creation of images. All stylistic devices appeal to the imagination of the listener and directly or indirectly through the background combine tiny details into a holistic image.

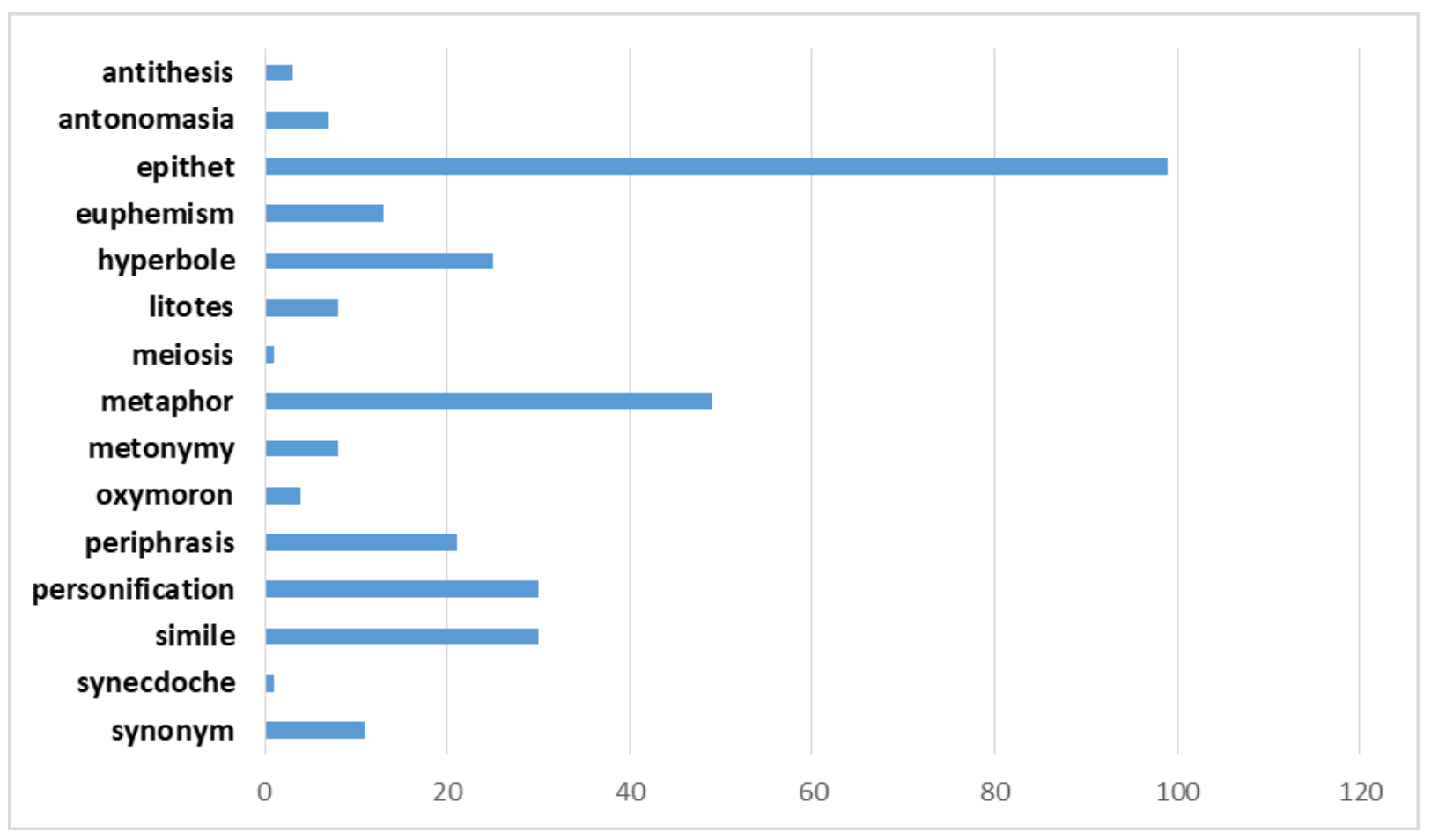

Figure 1. Quantitative representation of stylistic devices in the analysed folk song corpus

It is possible to assume that the reason for its high frequency index is the functions of the epithet to portray characters, views, situations, objects, and feelings and make texts 
more emotional, which match the respective functions of folklore. As the latter mirrors the society with its customs and traditions, it can explain the application of stylistic devices to describe characters and feelings.

\subsection{The epithet in descriptions}

All the epithets spotted in the analysed folk songs fall into several groups, which is illustrated in the classification below. The pie chart (see Fig. 2) shows that the most numerous group is represented by the epithets, which provide the descriptions of women (37\%). The second largest layer covers the descriptions of nature (31\%). Particular attention is paid to the descriptions of men's feelings $(25 \%)$ and miscellanea topics make up the smallest slice (7\%).

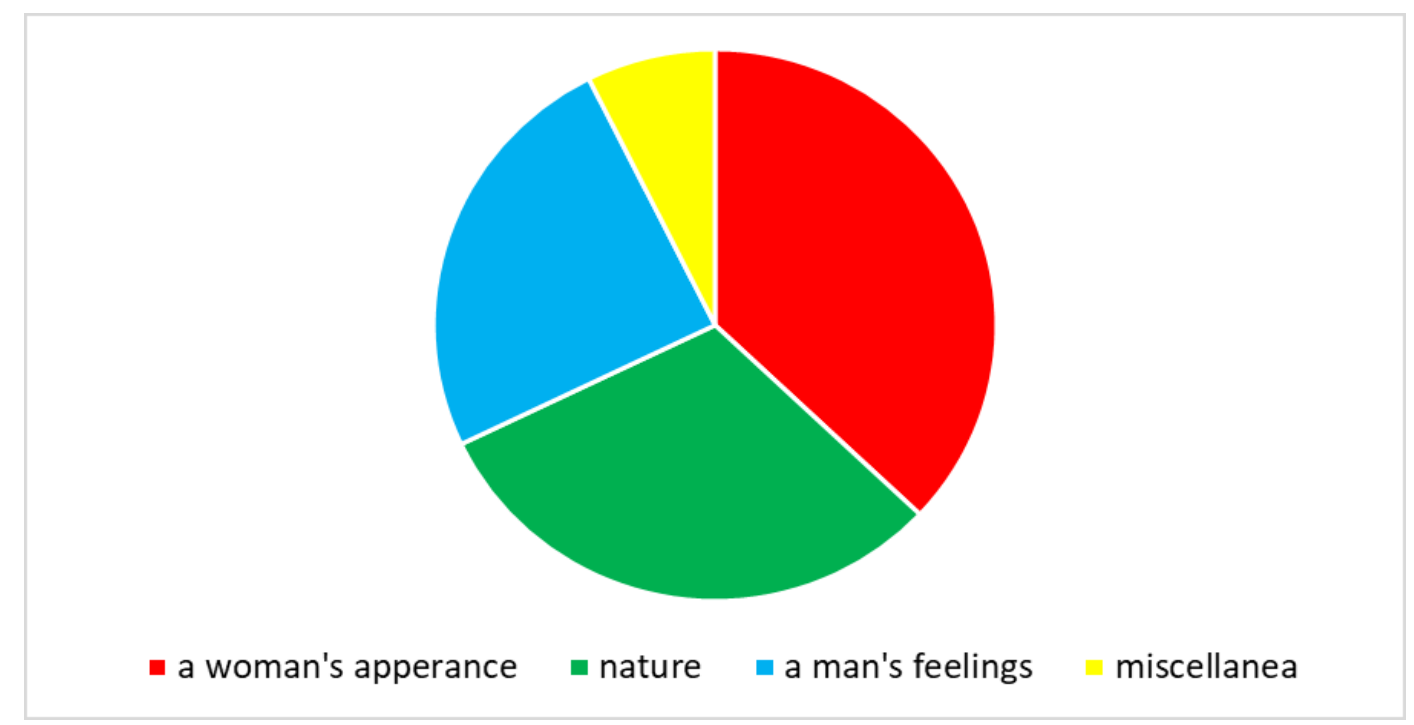

Figure 2. Epithets in descriptions of female images and their background

It has been found that the epithets, which refer to appearance characteristics, are mostly linked to face and general beauty patterns. For instance, the song "Dark eyes" emphasises the beauty of a lady's eyes:

Eyes of ecstasy always haunting me.

Always taunting me with your mystery! < .. >

Eyes so dark and dear, eyes of love and fear, 
Beautiful and true, I'm in love with you.

The folk song "Polly Wolly doodle" speaks of a funny girl Polly and her swop-like appearance:

Oh, my Sal, she is a maiden fair

Singin' Polly Wolly doodle all the day.

With curly eyes and laughing hair

Singin' Polly Wolly doodle all the day.

A pretty girl is described in the song "Lily of the West" with her cheeks and lips nicely focused on:

Her rosy cheeks, her ruby lips

Like arrows pierced my breast.

The name she bore was Flora,

The Lily of the West.

As far as female images are considered, the study shows it is typical of men to describe women's appearance thus eulogizing their beauty. The final part of this analysis will examine this issue in more detail (see 4.5.2). On the other hand, it has been discovered that the majority of the analysed folk songs (92\%) tend to be a man's part, i.e. when a man sings about a woman or about his feelings to her. In the former case, a man usually highlights a woman's beauty directly, while in the latter case he displays his feelings and emotions indirectly. Furthermore, the results thus obtained are compatible with those concerning sound symbolism (Stashko 2017). It is undeniable that men prefer to describe natural phenomena when they wish to convey their emotional status. Figure 2 shows significant percentage (31\%) to prove it. "The Colorado trail" is a case in point. It is a traditional cowboy song and therefore there is no need to doubt whether it is a man's part. To grasp the idea one should be acquainted with the whole song: 
1. Eyes like a morning star,

Cheeks like a rose;

Laura was a pretty girl,

God almighty knows.

2. Weep all you little rains,

Wail, winds, wail.

All along, along, along

The Colorado trail.

\section{Ride, all the lonely night}

Ride through the day,

Keep the herd a-movin' on

Movin' on its way.

\section{Dark is the stormy night,}

Dark is the sky.

Wish I'd stayed in Abilene,

Nice, and warm, and dry.

The first couplet has similes (eyes like a morning star, cheeks like a rose) to describe Laura's beauty. The second one has onomatopes (weep, wail) to mirror the man's sorrow on occasion of his paramour's death (see Stashko 2017 for the detailed analysis). The last two couplets feature several epithets, which describe nature. However, one should also agree that in reality they emphasise the man's lonely soul, his stormy life and dark mood without his woman.

Similar tunes are noticed in the 'farewell' song "Pretty Saro", where the man has to part with his love and shows his emotions through the epithets: 
Down in some lone valley,

In a lonesome place,

Where the wild birds do whistle,

And their notes do increase.

Farewell pretty Saro,

I bid you adieu.

But I'll dream of pretty Saro

Wherever I go.

Positive emotions can also be skilfully conveyed via nature-related epithets. As follows from the plot of the song "I'll take you home again, Kathleen", the man misses his wife Kathleen, while she is visiting her hometown. Apart from other epithets (loving eyes, true heart, loving heart, bonnie bride) used to emphasise his love, the epithets wild ocean and wide ocean in the first couplet show his strong desire to see her as soon as possible even if the distance is immense. The focus on green and fresh fields in the descriptions of Kathleen's arrival indicates her husband's sincere and inspiring hopes to see her.

I'll take you home again, Kathleen

Across the ocean wild and wide

To where your heart has ever been

Since you were first my bonnie bride.

The roses all have left your cheek.

I've watched them fade away and die.

Your voice is sad when e'er you speak

And tears bedim your loving eyes. 


\section{Chorus:}

Oh! I will take you back, Kathleen

To where your heart will feel no pain.

And when the fields are fresh and green,

I'll take you to your home again!

To continue the topic of separation and being sad but in love at the same time, see the folk song "Green grow the lilacs" and indulge yourself with the recollection of flowers and the current time being:

Green grow the lilacs, your favorite flow'r,

So sweetly perfuming - a sad parting hour.

Oh, send me a message - that you love me too,

Let's change the green lilacs to the Red, White and Blue.

So, I believe, shyness makes most men concentrate on the nearest or the strongest suitable object to convey their emotions and feelings and give listeners a clue how to interpret them. There are quite many logical bridges between a listener and the society, provided they are aware of generally accepted codes to understand fixed epithets.

\subsection{Types of epithets in popular and traditional folk songs}

Evaluating the dependence of epithet usage on the fact that a song has an author, it was found that the matter of authorship can be addressed to in connection to epithet types according to the semantic principle to illustrate how an individual's choice of stylistic devices differs from collective preferences. Based on the data in paragraph 3.2, representation of different epithet types has been analysed and structured respectively (see Fig. 3). 


\section{SEMANTIC PRINCIPLE}

\section{associated epithets}
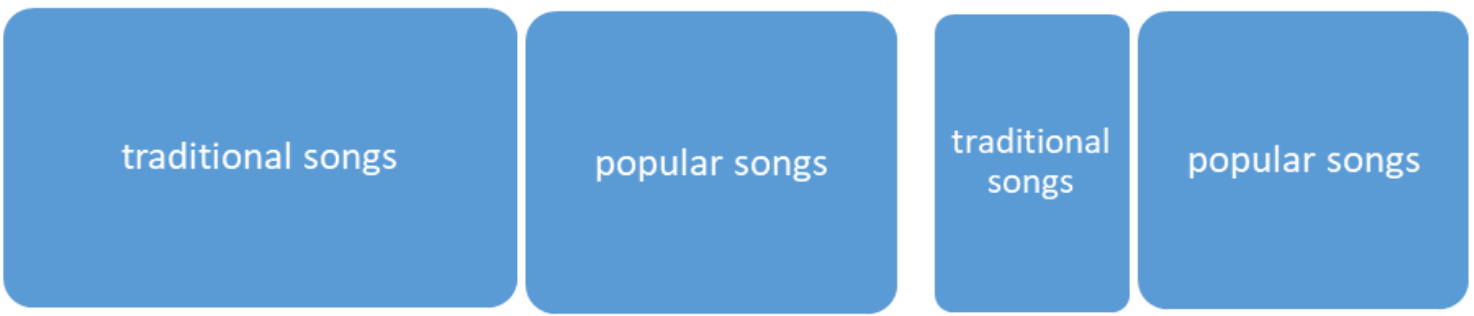

Figure 3. Representation of epithets in folk songs according to the semantic principle

From the outcome of the abovementioned calculations, it is possible to speak about associated epithets as of prevailing ones in the analysed traditional and popular American folk songs, to be more exact $67 \%$ of associated epithets versus $33 \%$ of unassociated epithets. This tendency can be explained by similarities in the folk song nature and the epithet itself. Associated epithets tend to simplicity whereas traditional folk songs are simple too. Such songs have been in constant usage among common people for centuries due to their catchy melody and simple lyrics. For example, the traditional American folk song "Lily of the West" about a woman, named Flora, the eponymous Lily of the West, contains the description of this beautiful woman with two associated epithets:

\section{Her rosy cheeks, her ruby lips}

Like arrows pierced my breast.

The name she bore was Flora,

The Lily of the West.

The brightest examples of associated epithets in popular American folk songs are:

(1) I come from Alabama 
With my banjo on my knee.

I'm goin' to Louisiana

My true love for to see.

("Oh! Susanna")

(2) The roses all have left your cheek.

I've watched them fade away and die.

Your voice is sad when e'er you speak

And tears bedim your loving eyes. <...>

To that dear home beyond the sea

My Kathleen shall again return.

And when thy old friends welcome thee,

Thy loving heart will cease to yearn.

("I'll take you home again, Kathleen")

"Oh! Susanna" was written by Stephen Foster, a famous American songwriter (Emerson 1998), in 1848 and "I'll take you home again, Kathleen" was created by Thomas Westendorf, a public school music teacher in Plainfield, Illinois (Hymnary, s.a.) in 1875. The latter song also contains unassociated epithets to describe the beauty of Kathleen's hometown Ogdensburg with a peaceful atmosphere:

Where laughs the little silver stream

Beside your mother's humble cot.

And brightest rays of sunshine gleam

There all your grief will be forgot.

The traditional folk song "Polly Wolly doodle" has some unassociated epithets and thus demonstrates how unconventional Polly's beauty is: 
Oh, my Sal, she is a maiden fair

Singin' Polly Wolly doodle all the day.

With curly eyes and laughing hair

Singin' Polly Wolly doodle all the day.

Therefore, it is clear that this tendency persists regardless of the authorship: both traditional and popular songs are abundant in associated and unassociated epithets.

According to the structural principle, epithets fall into five groups (see Paragraph 3.2), which are presented in American folk songs in different amounts. Figure 4 below roughly demonstrates their representation in American song folklore.

\section{STRUCTURAL PRINCIPLE}

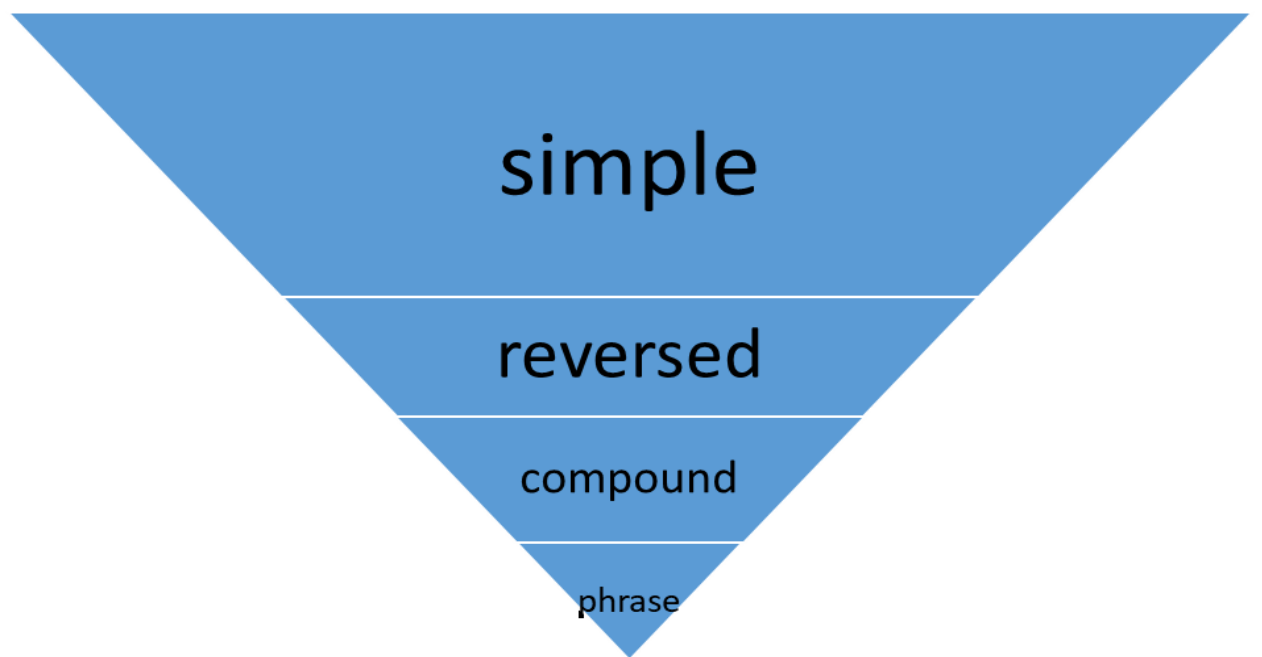

Figure 4. Representation of epithets in folk songs according to the structural principle

It is clear from the above that quantitatively the use of simple epithets in the analysed folk song corpus prevails over the use of other types of epithets twice. As this tendency is true for poetic texts and folk songs in particular (Galperin 1981), high recurrence of simple epithets is supposed to duplicate in traditional folk songs. However, the research has shown that simple epithets are equally presented in folk songs regardless of the author. The respective examples in popular American folk songs are sweet voice 
("Enraptured I gaze"), happy hours ("Darling Nelly Gray"), soft bubbles ("Clementine"). Traditional American folk songs feature the following examples of simple epithets: ruby lip ("Rattlesnake mountain"), true lover ("Charming beauty bright"), careless love ("Careless love"). The table below shows the examples of epithets in question.

Table 1. Representation of epithet types in American folk songs

\begin{tabular}{|c|c|c|}
\hline type of epithets / examples & $\begin{array}{l}\text { example of epithet in traditional } \\
\text { folk songs }\end{array}$ & $\begin{array}{l}\text { example of epithet in popular } \\
\text { folk songs }\end{array}$ \\
\hline simple epithets & $\begin{array}{c}\text { true lover } \\
\text { ("On top of Old Smoky") }\end{array}$ & $\begin{array}{c}\text { happy smile } \\
\text { ("Annie Lisle") }\end{array}$ \\
\hline reversed epithets & $\begin{array}{l}\text { song of hate } \\
\text { ("Careless love") }\end{array}$ & $\begin{array}{l}\text { eyes of ecstasy } \\
\text { ("Dark eyes") }\end{array}$ \\
\hline compound epithets & $\begin{array}{l}\text { sweetly perfuming flower } \\
\text { ("Green grow the lilacs") }\end{array}$ & - \\
\hline phrase epithets & $\begin{array}{l}\text { true-false lover } \\
\text { ("Tiny sparrow") }\end{array}$ & - \\
\hline sentence epithets & - & - \\
\hline
\end{tabular}

To put it another way, the research has shown no sentence epithets, probably, due to their complex structure, which is not typical of song folklore. The same is true for phrase and compound epithets in popular folk songs, though, they have been found in several traditional songs. Although it is necessary to point out that reversed epithets perform the expressive function attracting a listener's attention. Consider several representative examples within the text to have complete images, which handy illustrate the above-mentioned:

\section{(1) Eyes of ecstasy,}

Always haunting me.

Always taunting me

With your mystery!

Eyes so dark and dear, 


\section{Eyes of love and fear,}

Beautiful and true,

I'm in love with you,

Gleaming eyes of love,

Like the stars above,

You stole my heart,

May we never part.

("Dark eyes")

(2) Love, oh love, oh careless love,

Trusted you, now it's too late.

You've made me throw my old friend down,

That's why I sing this song of hate.

("Careless love")

\subsection{Recurrence of epithets}

The overall quantitative data on the use of simple epithets shows the adjective sweet as the most highly recurrent, happy goes second, and true is on the third place. The other cases are less frequent, but valuable in creating images.

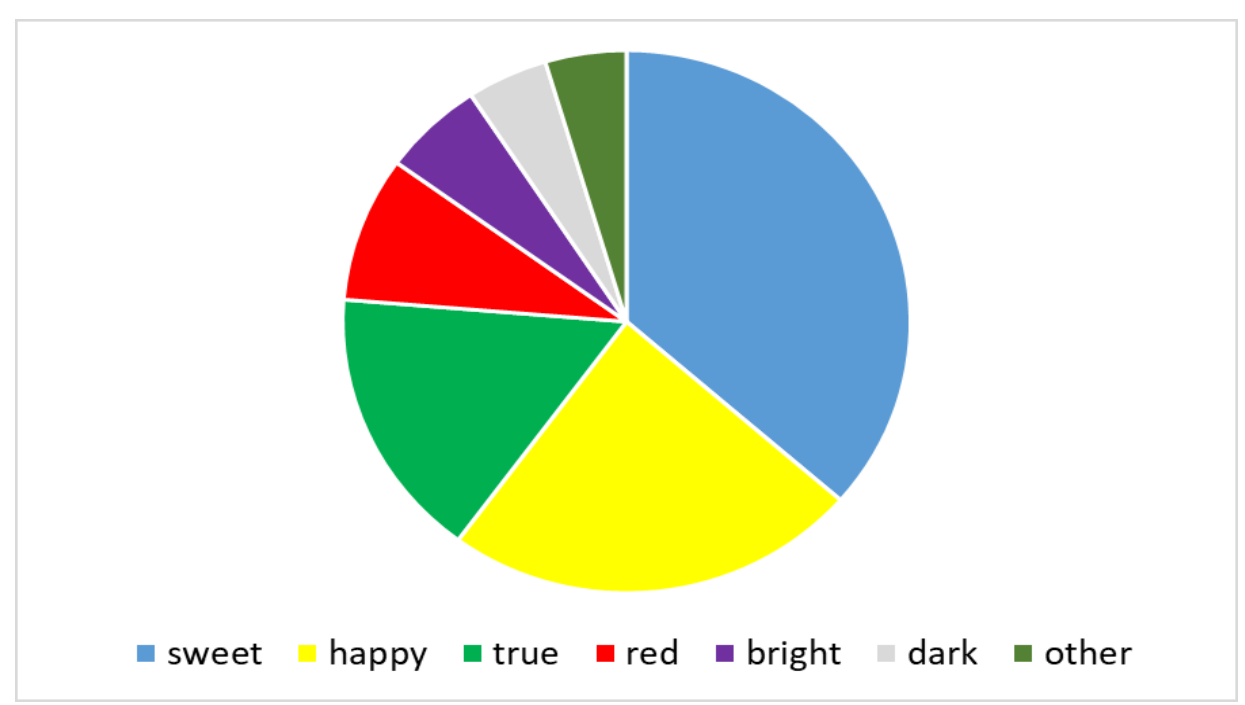

Figure 5. Recurrence of simple epithets 
To demonstrate the results shown in Figure 5 in detail, see the table of combinations from the analysed folk songs (Table 2).

Table 2. Highly recurrent combinations of simple epithets (adjective + noun)

\begin{tabular}{|c|c|}
\hline sweet & $\begin{array}{l}\text { - } \quad \text { sweet voice ("Enraptured I gaze") } \\
\text { - } \quad \text { sweet Lilly ("Lilly Dale") } \\
\text { - } \quad \text { sweet chiming ("Annie Lisle") }\end{array}$ \\
\hline happy & $\begin{array}{l}\text { - happy hours ("Darling Nelly Gray") } \\
\text { - happy smile ("Annie Lisle") } \\
\text { - happy top ("Wait for the wagon") }\end{array}$ \\
\hline true & $\begin{array}{l}\text { • } \text { true eyes ("Dark eyes") } \\
\text { • true love ("Oh! Susanna") } \\
\text { • true heart ("I'll take you home again, Kathleen") }\end{array}$ \\
\hline red/ruby/rosy & $\begin{array}{l}\text { - rosy cheeks ("Lily of the West") } \\
\text { - ruby lip ("Rattlesnake mountain") } \\
\text { - red lips ("Cotton-eyed Joe") }\end{array}$ \\
\hline bright & $\begin{array}{l}\text { - } \quad \text { bright eyes ("Red River valley") } \\
\text { - } \quad \text { bright night ("Sweet Betsy from Pike") } \\
\text { - } \quad \text { bright lips ("Katie Cruel") }\end{array}$ \\
\hline dark & $\begin{array}{l}\text { - dark damsel ("There is a tavern in the town") } \\
\text { - dark night ("Sweet Betsy from Pike") } \\
\text { - dark sky ("The Colorado trail") }\end{array}$ \\
\hline other & $\begin{array}{l}\text { - laughing hair ("Polly Wolly doodle") } \\
\text { - loving eyes ("I'll take you home again, Kathleen") } \\
\text { - } \quad \text { rotten tooth ("Rattlesnake mountain") }\end{array}$ \\
\hline
\end{tabular}




\subsection{Description of female images in American folk songs}

Bearing in mind all the previously stated aspects it is worth noting that the epithet is one of the handiest means in creating female images and general atmosphere of the stories' background. Consequently, let us consider the key observations on the given issue.

\subsubsection{Colour in epithets to describe women}

Epithets based on colour or colour tinctures appear to make up the most numerous group. Description of body parts or nature in colours contributes to expressiveness and helps build up true or subjectively true image elements. A woman is compared to the colour wishing flower (see Fig. 6), which has only positive connotation and is perceived as an idol to obey. It is remarkable of American song folklore to depict women of different background, style, and social status in the extremely respected way.

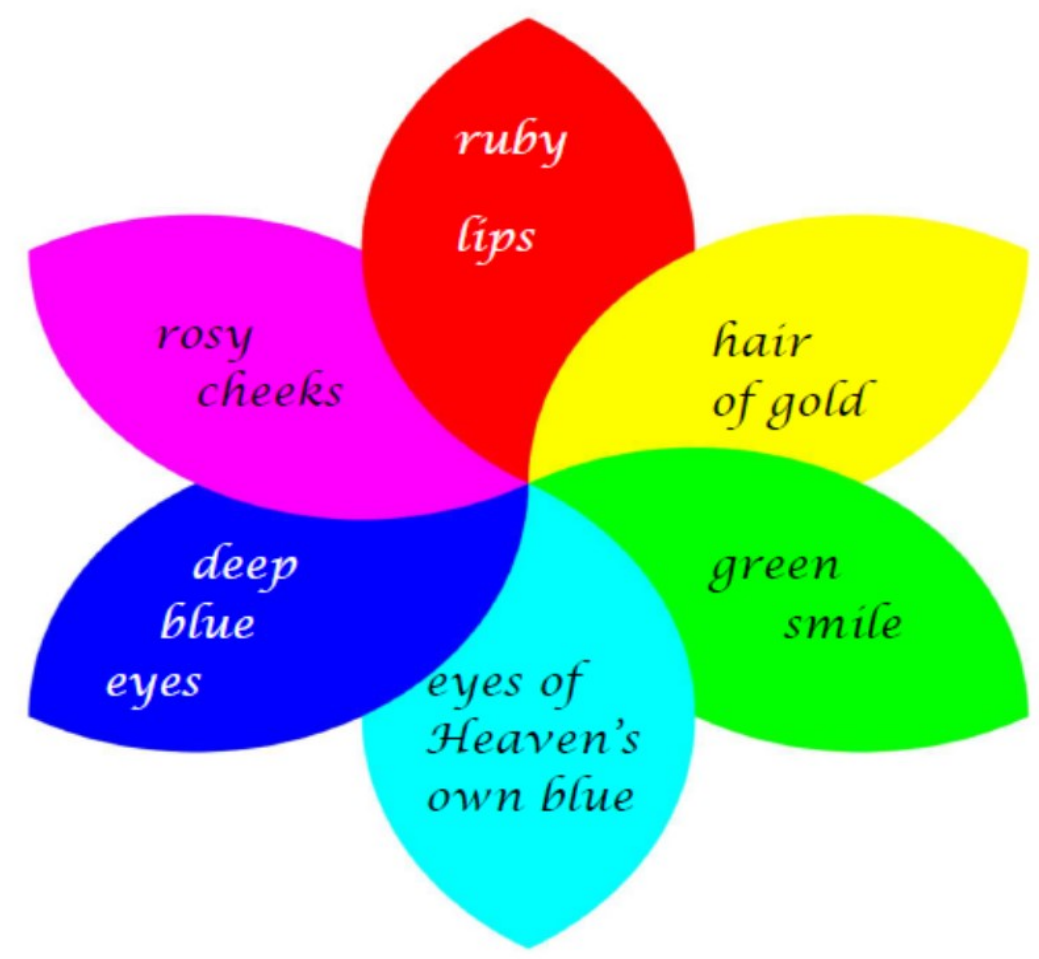

Figure 6. Colour aspect in epithets

Besides, it must be noted that colours are skilfully embedded in descriptions of feelings, nature, or general atmosphere. All possible colours are used to create tiny details, which can be seen in the figure below (Fig. 7). 


\begin{tabular}{|c|c|}
\hline red & \multicolumn{1}{c|}{ lips, } \\
\hline rosy & $\bullet$ cheeks, lips \\
\hline ruby & $\bullet$ lips \\
\hline gold & $\bullet$ hair, sun \\
\hline green & $\bullet$ smile, valley, grave \\
\hline blue & $\bullet$ eyes, skies, mountain \\
\hline silver & $\bullet$ hair, moon, stream \\
\hline black & $\bullet$ eyes, damsel, night \\
\hline bright & $\bullet$ eyes, sky, moon \\
\hline dark & $\bullet$ hair, sky, night \\
\hline
\end{tabular}

Figure 7. Colour representation in epithets

\subsubsection{Descriptions of women's appearances in epithets}

The study results showed that describing a woman it is appropriate to use epithets that depict her beauty. In the creation of female images the most commonly used epithets are related to body parts, that is to eyes (curly eyes, dark eyes), lips (ruby lips, red lips), cheeks (rosy cheeks, red cheeks), etc. For example, the figure below (Fig. 8) presents rich abundance of epithets, which are connected with hair.

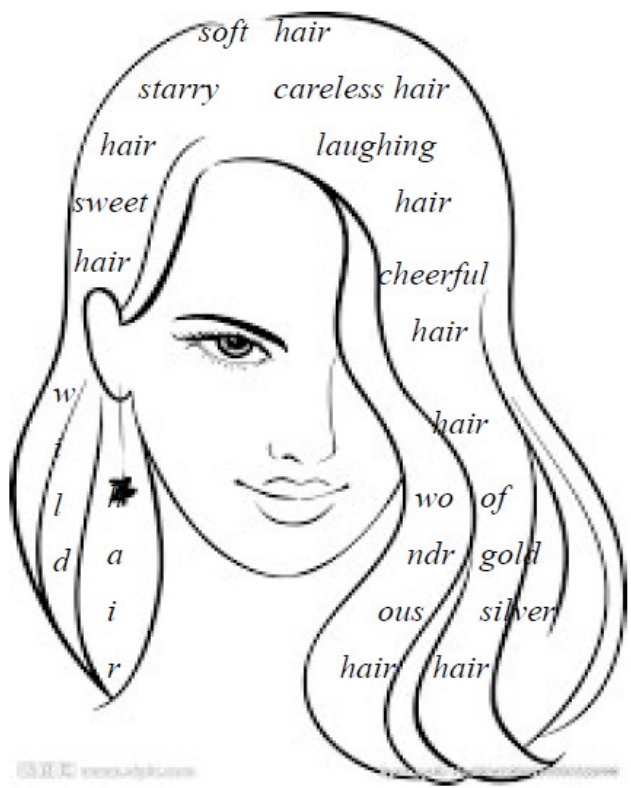

Figure 8. Epithets in descriptions of hair. Picture available at http://www.fotosearch.com/CSP990/k11062129/ 
Here are several examples of their use in folk songs to make up female images:

(1) I love the grass whereon she stands,

She with the wondrous hair.

("Black is the color of my true love's hair")

(2) In the most graceful curls hangs her raven black hair,

And she never requires perfumery there.

("Dear Evelina, sweet Evelina")

(3) Oh, my Sal, she is a maiden fair

Singin' Polly Wolly doodle all the day.

With curly eyes and laughing hair

Singin' Polly Wolly doodle all the day.

("Polly Wolly doodle")

(4) When, at first, she met a winsome Johnny,

He wasn't sure her heart was pure.

Her eyes were far too bold.

So, round her neck

He tied a yellow ribbon,

He tied a yellow ribbon,

'Cause it matched her hair of gold.

("She wore a yellow ribbon")

Generally, cases of epithets that contain body parts also tend to a certain hierarchy in usage. As it was illustrated above, epithets that describe hair have the highest recurrence. Epithets, which depict eyes, are numerous too. To visualise the matter, one can refer to Figure 9. 


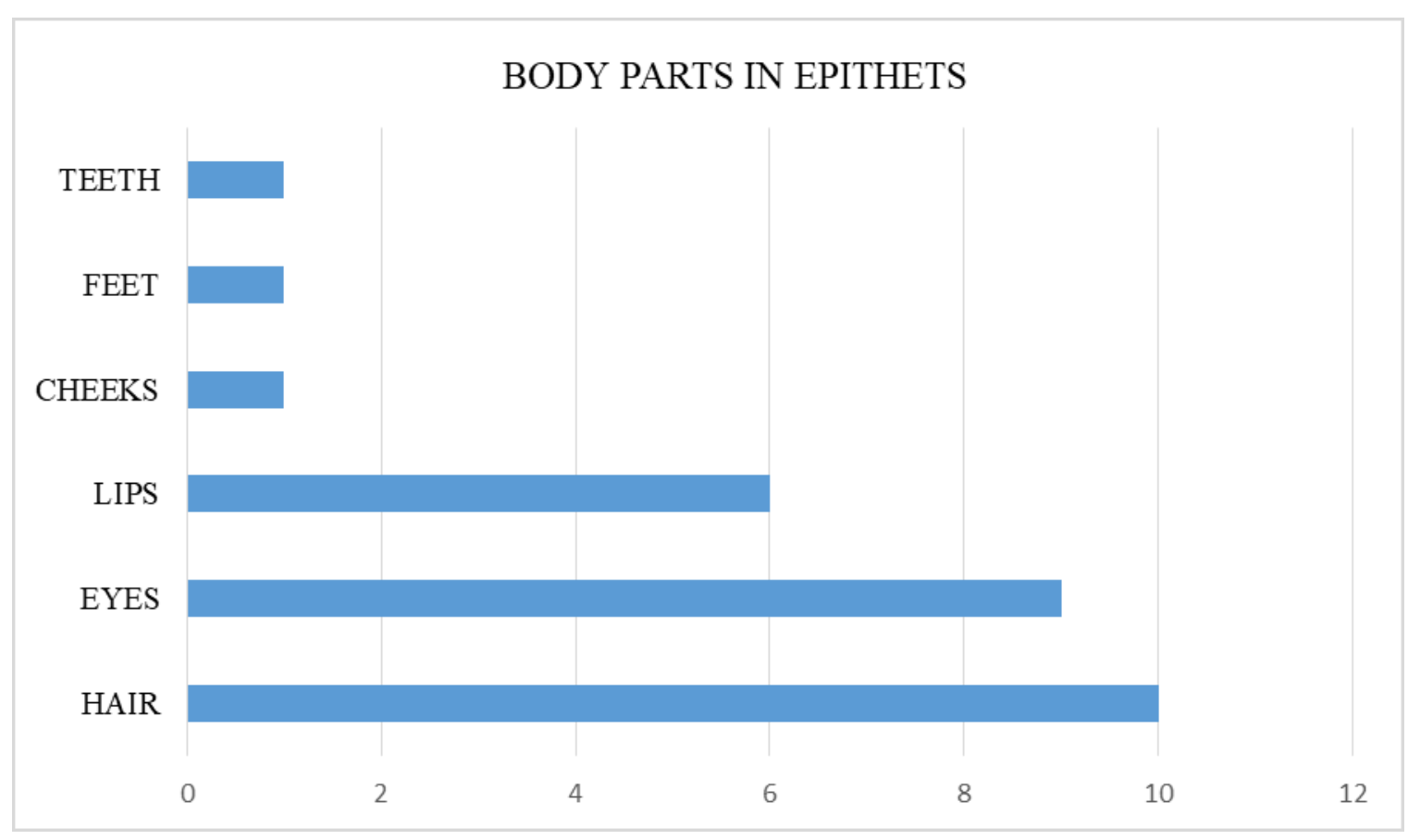

Figure 9. Recurrence of epithets in descriptions of body parts

\subsubsection{Emotions and perception in epithets}

American folk songs feature extremely beautiful female images, which are addressed to through stylistic devices highlighting emotional states of both a woman and a man. It has been found that epithets based on evaluative adjectives that express emotions are primarily important to show feelings of love (eyes of ecstasy, careless love, loving eyes) and hatred (song of hate), sorrow (bad ends) and happiness (happy smile, happy hours), loneliness (lonely night, lonely prairie) or sadness (sad parting hour). One of the examples to portray emotional status of the characters is the traditional song "Green grow the lilacs", which describes a story of an American soldier's love for a Mexican lass during the Mexican-American War:

Green grow the lilacs, all sparkling with dew.

I'm lonely, my darling, since parting with you.

But by our next meeting I'll hope to prove true And change the green lilacs to the Red, White and Blue.

Green grow the lilacs reminding me of 
The ones that I brought you with all of my love.

The gates of my country will open for you

And change the green lilacs to the Red, White and Blue.

Green grow the lilacs, your favorite flow'r,

So sweetly perfuming - a sad parting hour.

Oh, send me a message - that you love me too,

Let's change the green lilacs to the Red, White and Blue.

The young couple mirrors emotions and feelings of other couples who had to stay separately due to certain sad circumstances. A similar case is described in the popular song "Darling Nelly Gray" written by Benjamin R. Hanby:

There's a low green valley

On the old Kentucky shore,

There I've whiled many happy hours away.

$A$ sitting and a singing

By the little cottage door,

Where lived my darling Nelly Gray.

Oh! My poor Nelly Gray,

They have taken you away,

And I'll never see

My darling any more.

I'm a sitting by the river

And I'm weeping all the day,

For you've gone from the

Old Kentucky shore. 
It is based on the story of a slave named Nelly Gray who was sold away from her home and family. It is said that the tune was inspired by a runaway slave named Joseph Selby who hoped to earn sufficient money in Canada to buy the freedom of his sweetheart. One version of the story says that Nelly was traded to a Georgia slaveholder on the day before she and Selby were to be married.

It appears that both stories contain epithets based on the opposition 'happy hour-sad hour', but they are similar emotionally. Both couples convey their sorrow and loneliness even recollecting happy hours.

One more cluster of epithets is represented by perception words connected mainly with flavours (sweet smile, sweet hours, sweet voice, rotten teeth, rotten jail) and tactile aspects (soft voice, soft music). Moreover, quite a number of songs contain epithets with the adjective sweet in names (Sweet Lilly, Sweet Phyllis, Sweet Biddie Magie). The most likely explanation of such findings is a desire to show how dear and loved a woman is.

\subsubsection{Epithets with negative connotation}

At the next stage of the research, my attention was focused not only on positive but also on negative female images. Clearly, Americans tend to avoid negative female images, which has been illustrated by numerous examples herein. So far, the analysed folk song corpus has several epithets with negative connotation to describe women (Katie Cruel, false-hearted lover).

The image of a cruel girl named Katie in the song "Katie Cruel" has contrastive descriptions. The image itself conveys positive impressions (eyes as bright as coal, lips as bright as cherry), as the girl changed due to love matters (I go through the woods to my heart's desire). She needs to be strong to survive in a new town; thus, her virtuous traits are shown as dominant whereas the word 'cruel' in her name can be explained by the circumstances mentioned in the storyline. 
"On top of Old Smokey" with two contrastive epithets (true love, false-hearted lover) and one metaphor (a false-hearted lover is a thief) contribute to the image of a liar (She'll hug you and kiss and tell you more lies than the cross ties on the railroad or the stars in the skies). Her unlucky paramour feels sad and gloomy (on top of Old Smokey I went there to weep), but this situation is his fault (I lost my true lover for a courtin' too slow), which justifies her.

Hence, it has been demonstrated that even words with negative connotation do not convey negative emotions towards evil female images. Women in America are loved and respected regardless of any conditions or features of their character.

\subsubsection{Features typical of American women depicted with the help of epithets}

The evidence suggests that in general any female image in American folk songs is treated positively and emotionally. A woman seems a goddess doted on, whose beauty is undoubtedly obvious to everyone. Subjectively summing up the depicted characteristics of an average American woman, it is possible to brief them in the following list (see Fig. 10):

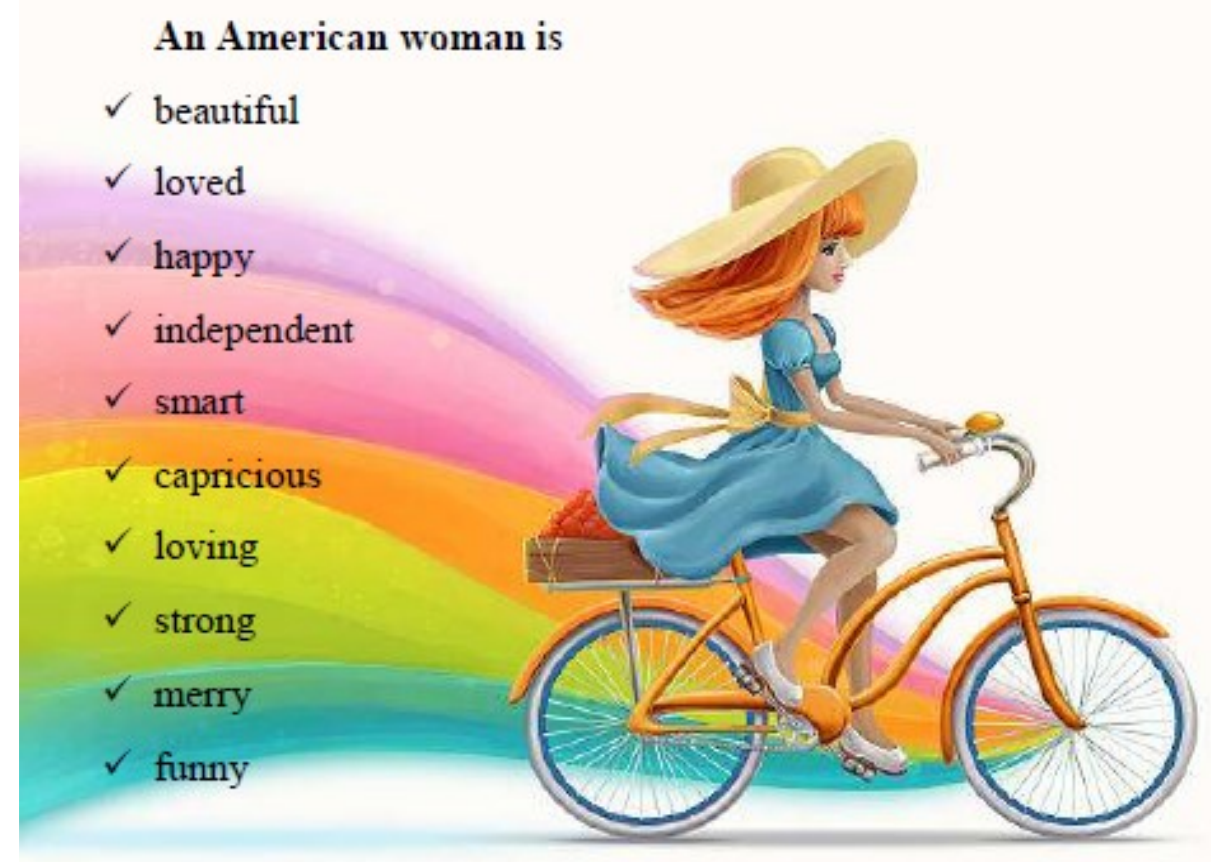

Figure 10. Features typical of an American woman. Picture available at https://pt.depositphotos.com/43670671/stock-photo-drawing-beautiful-girl-riding-a.html 


\section{Conclusions and perspectives}

To conclude, the study of epithets in American folk songs has discovered the position or status of an American woman who has been treated equally with men, with no single sign of gender slur. The study shows that the most possible reason is the status quo of America, which has always declared democratic and freedom-oriented views. Moreover, American folklore also keeps evidence of such views providing descriptions of women's evolution throughout ages in terms of their background, family, identity and mentality matters, and social status. To put it another way, the results of the stylistic analysis of the selected American folk songs have shown the connection between semantics and culture.

The performed analysis testifies to the fact that the epithet may successfully be applied into creation of true female images as the indicated stylistic device predominantly focuses on a woman's advantageous traits thus making a listener apply his imagination when reconstructing and decoding female images.

It has been found that a woman is generally described directly through epithets and other stylistic devices depicting her appearance, beauty, character, and behaviour. Feelings to her as well as of hers are mostly conveyed through background elements, and nature in particular.

In general, most female images in American song folklore are positive, balanced, and harmonious, and only a few cases indicate that American society is not perfect, and there are good and evil people. As the common central element in both positive and negative female images is beauty, the vast majority of images are perceived empathically.

Quantitatively, the results have also shown a tendency for associated epithets to be used mainly in traditional songs while popular songs mainly involve unassociated ones, while popular songs mainly involve unassociated ones. It is also worth noting that 
simple epithets outnumber reversed and compound epithets quantitatively in creating female images. Absence of epithets in songs does not simplify or water the characters' features down, as this function is often transferred to melody and other stylistic devices, though the epithet appeared to be the most recurrent one.

Based on the promising findings presented in this paper, work on the remaining issues on the semantic level is being continued and will be presented in upcoming papers.

\section{List of abbreviations}

CED - Collins English dictionary

CFEDT - Cambridge free English dictionary and thesaurus

EOLD - English Oxford living dictionary

MWOD - Merriam-Webster online dictionary

\section{References}

Appleby, A. \& Stone, J. (1991). America's all-time favorite songs. New York-LondonSydney: Amsco Publications.

Banfield, A. (1982). Unspeakable sentences: Narration and representation in the language of fiction. Boston: Routledge \& Paul.

Bauman, R. \& Abrahams, R.D. (1981). "And other neighborly names": Social process and cultural image in Texas folklore. Austin: University of Texas Press.

Brunvand, J. (1978). The study of American folklore: An introduction. $2^{\text {nd }}$ ed. New York: W.W. Norton.

Cambridge free English dictionary and thesaurus. Available at: https://dictionary.cambridge.org/dictionary/english/epithet

Carroll, L. (2016). The complete Lewis Carroll collection (illustrated). Edmonton: Tyché.

Collins English dictionary. Available at:

https://www.collinsdictionary.com/dictionary/english/epithet

Ginger (symbol). Available at: http://lzmarieauthor.com/tag/ginger-symbolism/ 
Emerson, K. (1998). Doo-dah! Steven Foster and the rise of American popular culture. Boston: Da Capo Press.

English Oxford living dictionary. Available at:

\section{https://en.oxforddictionaries.com/definition/epithet}

Galperin, I.R. (1981). Stylistics. Moscow: Vysshaya shkola.

Halliday, M.A.K. \& Matthiessen, C.M.I.M. (2004). Introduction to functional grammar. London: Edward Arnold.

Hymes, D. (1981). In vain I tried to tell you: Essays in Native American ethnopoetics. Philadelphia: University of Pennsylvania Press.

Hymnary. Westendorf Thomas. Available at:

\section{https:/hymnary.org/person/Westendorf Thomas}

Kingman, D. (1990). American music. A panorama. New York: Simon and Schuster Macmillan.

Levitsky, A. (2016). Language worldview of Yakima Indians, compared with English and Ukrainians. In Lege artis. Language yesterday, today, tomorrow. The journal of university of SS Cyril and Methodius in Trnava, Warsaw: De Gruyter Open, vol. I (2), December 2016, p. 80-128. DOI: 10.1515/lart-2016-0011 ISSN 2453-8035 Malkoç, A.M. (1994). Old favorites for all ages. Washington: USIA.

Merriam-Webster online dictionary. Available at: https://www.merriamwebster.com/dictionary/epithet

Panasenko, N. (2013). Melodic component as the means of expressing emotions and feelings in Ukrainian and American folk love songs. In International journal of arts and commerce, 2 (7), p. 142-154.

Panasenko, N. (2014). Musical and linguistic means of creating images in traditional and popular American songs. In Review of arts and humanities, 3 (1), p. 23-43.

Raph, Th. (1986). The American song treasury. 100 favorites. New York: Dover Publications.

Sandburg, C. (1936). The people, yes. New York: Mariner Books.

Stashko, H.I. (2016). Female images in American song folklore: Linguostylistic and linguoculturological aspects. Thesis for the Candidate Degree in Philology, Speciality 
10.02.04 - Germanic languages. Kyiv: Kyiv National Linguistic University. / Stashko H.I. Zhinochi obrazy v amerykans'komu pisennomu fol'klori: Linhvostylistychnyj ta linhvokul'turolohichnyj aspekty. Dysertatsiya na zdobuttya vchenoho stupenya kandydata filolohichnykh nauk. Kyyiv: Kyyivs'kyj natsional'nyj linhvistychnyj universytet. / Сташко Г.І. Жіночі образи в американському пісенному фольклорі: Лінгвостилістичний та лінгвокультурологічний аспекти / Дис. ... канд. філол. наук / Київ: Київський національний лінгвістичний університет. 10.02 .04 германські мови.

Stashko, H. (2016a). Sound symbolism in female images creation (based on American song folklore). In Science and education a new dimension. Philology, IV (20), Iss. 85, p. 60-63. Available at: http://scaspee.com/all-materials/sound-symbolism-in-femaleimages-creationbased-on-american-song-folklore-stashko-h

Stashko, H. (2017). When phonetics matters: Creation and perception of female images in song folklore. In Lege artis. Language yesterday, today, tomorrow. The journal of university of SS Cyril and Methodius in Trnava, Warsaw: De Gruyter Open, vol. II (1), June 2017, p. 299-335. DOI: 10.1515/lart-2017-0008

Volkova, S. (2016). Reverse perspective as a narrative technique in Amerindian prosaic texts. In Lege artis. Language yesterday, today, tomorrow. The journal of university of SS Cyril and Methodius in Trnava, Warsaw: De Gruyter Open, vol. I (1), June 2016, p. 359-394. DOI: 10.1515/lart-2016- 0008

Wales, K. (2001). A dictionary of stylistics. Harlow-New York: Longman.

\begin{tabular}{|l|l|}
$\quad$ Contact data & \multicolumn{1}{|c|}{ Fields of interest } \\
$\quad$ CSalyna Stashko (Philology), \\
Senior Lecturer \\
Interpreters' / Translators' \\
Department, Kyiv National \\
Linguistic University, 73, \\
Velyka Vasyl'kivs'ka St., \\
Kyiv, 03680, Ukraine. \\
e-mail: \\
galinastashko@gmail.com
\end{tabular}




\section{Résumé in English}

This paper describes the use of epithets in creating female images in American folk songs. As America has always been democratic and freedom-oriented, its folklore provides case studies of establishment of women throughout ages in terms of their background, family, identity and mentality matters, and social status. Therefore, the results of the stylistic analysis have shown the connection between semantics and culture and provided valuable clues, which help understand the evolution of a woman in America, who has been treated equally with men, with no single sign of gender slur. The selected American folk songs with female images have been analysed with the help of quantitative and qualitative analyses, which let define the role of the epithet in creating images. Considering multifunctionality of the epithet to be descriptive, expressive, evaluative, and individualizing in poetic texts, this research focuses on its portraying characters, views, situations, objects, feelings, and emotions. A woman is generally described directly through epithets and other stylistic devices depicting her appearance with the emphasis on face and general beauty patterns, character and behaviour. Feelings to her as well as of hers are mostly conveyed through descriptions of background elements, and nature in particular. The indicated stylistic device predominantly focuses on a woman's advantageous traits, while most female images in American song folklore are positive, balanced, and harmonious. As the common central element in both positive and negative female images is beauty, the vast majority of images are perceived empathically. Absence of epithets in songs does not simplify descriptions of characters, as this function is often transferred to melody and other stylistic devices, though the epithet appeared to be the most recurrent one. The results have also shown a tendency to feature more associated epithets in traditional songs while popular songs mostly have unassociated ones. According to the structural principle, simple epithets outnumber reversed and compound epithets quantitatively in creating female images.

Key words: epithet, classification of epithets, epithet structure, female images, American song folklore. 


\section{Résumé in German (translation by Alla Kapusch)}

In diesem Artikel wird die Verwendung von Epitheta bei der Schaffung von Frauengestalten in den amerikanischen folkloristischen Liedern beschrieben. Da Amerika immer demokratisch und freiheitsorientiert war, stellt seine Folklore ein Modell des Werdens der Frau im Laufe der Jahrhunderte dar - unter Berücksichtigung ihrer Herkunft, ihrer Rolle in der Familie, des sozialen Status sowie der Identitäts- und Mentalitätsfragen. Die Ergebnisse der stilistischen Analyse zeigten die Verbindung zwischen Semantik und Kultur und lieferten wertvolle Indikatoren, die die Evolution der Frau in Amerika zu verstehen helfen, die durch Gleichberechtigung mit Männern und Abwesenheti von Geschlechtsdiskriminierung gekennzeichnet wird. Die in der Stichprobe erfassten amerikanischen folkloristischen Lieder mit Frauengestalten sind mit Hilfe der quantitativen und qualitativen Analyse analysiert worden, was erlaubt hat, die Rolle von Epitheta bei der Schaffung von Gestalten zu bestimmen. In Anbetracht der Multifunktionalität des Epithetons und seiner beschreibenden, expressiven, bewertenden und individualisierenden Rolle in den poetischen Texten fokussiert sich diese Forschung auf die Verwendung des Epithetons für die Beschreibung von handelnden Pesonen, Ansichten, Situationen, Gegenständen, Gefühlen und Emotionen. Die Frau wird gewöhnlich unmittelbar durch Epitheta und andere stilistische Mittel beschrieben, die ihr Äußeres, besonders das Gesicht und allgemeine Schönheitsmerkmale, ihren Charakter und ihr Verhalten betonen. Die Gefühle ihr gegenüber sowie ihre eigene Gefühle werden im Allgemeinen durch Beschreibungen von Hintergrundelementen und vor allem Natur wiedergegeben. Das genannte stilistische Mittel betont überwiegend vorteilhafte Züge der Frau, während die meisten Frauengestalten im amerikanischen folkloristischen Liedgut positiv, ausgeglichen und harmonisch sind. Da das gemeinsame zentrale Element sowohl bei den positiven als auch bei den negativen Frauengestalten Schönheit ist, werden die meisten Gestalten empathisch empfunden. Abwesenheit von Epitheta in Liedern führt nicht zu einer Simplifizierung der Beschreibung von handelnden Personen, weil diese Funktion oft durch Melodie und andere stilistische Mittel vermittelt wird; aber das Epitheton ist das meist gebrauchte Mittel. Die Ergebnisse haben auch die Tendenz zur 
Verwendung von assoziierten Epitheta in traditionellen Liedern gezeigt, während in populären Liedern hauptsächlich nichtassoziierte Epitheta vorkommen. Dem Strukturprinzip folgend, übersteigt die Zahl der einfachen Epitheta die Zahl der invertierten und zusammengesetzten Epitheta bei der Schaffung von Frauengestalten.

Stichwörter: Epitheton, Klassifikation der Epitheta, Struktur des Epithetons, Frauengestalten, amerikanisches folkloristisches Liedgut.

\section{Résumé in French (translation by Dmytro Borys)}

Cet article décrit l'utilisation d'épithètes dans la création d'images féminines dans des chansons folkloriques américaines. Comme l'Amérique a toujours été démocratique et orientée vers la liberté, son folklore fournit des études de cas sur la socialisation des femmes à travers les âges en termes de leurs origines, de leurs rôles dans des familles, de leurs identités et de leurs mentalités. Par conséquent, les résultats de l'analyse stylistique ont montré un lien entre la sémantique et la culture ce qui fournit des indices précieux pour comprendre l'évolution de la femme en Amérique, traitée à égalité avec les hommes, sans aucun signe de discrimination sexuelle. Les chansons populaires américaines sélectionnées qui contiennent des images féminines ont été étudiées à l'aide d'analyses quantitatives et qualitatives ce qui a permis de définir le rôle de l'épithète dans la création d'images. Tenant compte de la multifonctionnalité de l'épithète aussi bien que son ensemble de rôles - descriptif, expressif, évaluatif et individualisant - dans les textes poétiques, cette recherche se concentre sur l'utilisation de l'épithète dans la représentation de caractères, de vues, de situations, d'objets, de sentiments et d'émotions. Une femme est généralement décrite directement par des épithètes et d'autres dispositifs stylistiques portant sur son apparence physique avec l'accent sur le visage et les modèles de beauté standardisée, le caractère et le comportement. Les sentiments éprouvés pour elle et par elle-même sont principalement rendus à l'aide des descriptions d'éléments de fond, et de la nature en particulier. Le dispositif stylistique ci-dessus se concentre principalement sur les traits avantageux de la femme, tandis que la plupart des images féminines du folklore américain sont 
positives, équilibrées et harmonieuses. Comme l'élément central unissant les images féminines positives et négatives est la beauté, la grande majorité des images sont perçues avec de l'empathie. Néanmoins, l'absence d'épithètes dans les chansons ne simplifie pas la description des personnages, car cette fonction est souvent transférée à la mélodie et à d'autres dispositifs stylistiques. Pourtant, l'épithète est le plus récurrent parmi ces derniers. Les résultats ont également montré une tendance à inclure des épithètes associées dans des chansons traditionnelles alors que des chansons populaires contiennent des épithètes non-associées. Selon le principe structurel, les épithètes simples sont plus nombreuses dans la création d'images féminines que les épithètes inversées et composées.

Mots-clés: épithète, classification des épithètes, structure de l'épithète, images féminines, folklore de la chanson américaine.

\section{Résumé in Russian}

В этой статье описывается использование эпитетов при создании женских образов в американских фольклорных песнях. Поскольку Америка всегда была демократичной и ориентированной на свободу, ее фольклор представляет модель становления женщины на протяжении веков учитывая ее происхождение, роль в семье, социальный статус, а также вопросы идентичности и менталитета. Поэтому результаты стилистического анализа показали связь между семантикой и культурой и предоставили ценные индикаторы, которые помогают понять эволюцию женщины в Америке, отношение к которой не имеет признаков гендерной дискриминации. Вошедшие в выборку американские фольклорные песни с женскими образами были проанализированы с помощью количественного и качественного анализа, что позволило определить роль эпитетов в создании образов. Учитывая мультифункциональность эпитета и его описательную, выразительную, оценочную и индивидуализирующую роли в поэтических текстах, это исследование фокусируется на использовании эпитета для описания персонажей, взглядов, ситуаций, предметов, чувств и эмоций. 
Женщина обычно описывается непосредственно через эпитеты и другие стилистические средства, которые акцентируют ее внешность, особенно лицо, и стандартные красивые черты, ее характер и поведение. Чувства к ней, как и ее чувства, в основном, передаются через описания элементов фона и, в частности, природы. Указанное стилистическое средство преимущественно подчеркивает выигрышные черты женщины, в то время как большинство женских образов в американском песенном фольклоре являются положительными, сбалансированными и гармоничными. Поскольку общий центральный элемент как в положительных, так и в отрицательных женских образах - красота, большинство образов воспринимается эмпатически. Отсутствие эпитетов в песнях не приводит к симплификации описания персонажей, так как эта функция часто передается через мелодию и другие стилистические средства, при этом эпитет есть наиболее рекуррентным. Результаты также показали тенденцию к использованию ассоциированных эпитетов в традиционных песнях, в то время как в популярных песнях в основном встречаются неасоциированные эпитеты. Согласно структурному принципу простые эпитеты количественно превосходят инвертированные и составные эпитеты при создании женских образов.

Ключевые слова: эпитет, классификация эпитетов, структура эпитета, женские образы, американский песенный фольклор.

Article was received by the editorial board 6.11.2017.

Reviewed 8.11.2017 and 10.11.2017

Similarity Index 19\% 